\title{
Drug Product Life-Cycle Management as Anticompetitive Behavior: The Case of Memantine
}

\author{
Vincent C. Capati, PharmD, MS, and Aaron S. Kesselheim, MD, JD, MPH
}

\begin{abstract}
SUMMARY
A "product hop" involves the substitution of a new formulation of a prescription drug by a pharmaceutical manufacturer for an old version to forestall generic competition. In 2015, for example, Forest Laboratories, the brand-name drug manufacturer of memantine, an Alzheimer's disease treatment, introduced an extended-release version and tried to restrict patient access to the previous version. Product hops can lead to useful incremental innovation but can also have major public health implications by disrupting patients on stable treatment regimens and increasing costs for patients and payers. This commentary reviews alleged anticompetitive product hopping in the case of memantine, which involved proposed conduct that would have left Alzheimer's disease patients with no effective choice but to transition to memantine XR. Policy solutions that can limit anticompetitive product hops include raising the bar for obtaining patents on new drug product formulations and changing automatic generic substitution laws.
\end{abstract}

J Manag Care Spec Pharm. 2016;22(4):339-44

Copyright $\odot 2016$, Academy of Managed Care Pharmacy. All rights reserved.

$\mathrm{P}$ roduct life-cycle management is a business strategy that pharmaceutical manufacturers use to maintain revenue streams from their leading drug products. ${ }^{1}$ One of the most common tactics for avoiding generic competition is "product hopping": the introduction of a new drug formulation that is protected by a competition-free period. ${ }^{2}$ For example, Abbott twice introduced new formulations of fenofibrate (TriCor) first by moving from capsules to tablets, then by slightly altering the tablet strength, just as the generic version was ready to launch. ${ }^{3}$ Generic competition was delayed because it took the generic manufacturer time to reformulate its product and earn U.S. Food and Drug Administration (FDA) approval. Warner Chilcott successfully debuted multiple doxycycline hyclate (Doryx) products-product hopping from capsules to tablets to new strengths to tablet scoring changes. ${ }^{4}$ AstraZeneca introduced esomeprazole (Nexium) ${ }^{5}$ - the purified s-enantiomer of the racemic omeprazole (Prilosec) ${ }^{6}$-as the new purple pill. ${ }^{7}$ Previously marketing omeprazole as the purple pill, ${ }^{8}$ AstraZeneca changed the color to salmon pink, while making it available over the counter. In these product hops, drugmakers introduced the new drug while moving marketing away from-and sometimes discontinuing production of or increasing prices of - the older formulation. ${ }^{9}$
As these examples indicate, product life-cycle management strategies tend to interfere with timely generic competition, ${ }^{10,11}$ raising prescription drug costs for patients and payers. ${ }^{12}$ This interference makes the practice controversial because numerous studies indicate that when low-cost generic drugs are available, patient adherence to essential medication regimens increases, and public health outcomes can improve. ${ }^{13}$ However, product life-cycle management can also be beneficial for patients if the new formulation offers substantial reductions in side effects or if the new product improves convenience. The introduction of once-a-day metoprolol succinate (Toprol XL), as a follow-on formulation to 4-times-a-day metoprolol tartrate (Lopressor), dramatically reduced daily pill burden for patients.

How far can companies go in transitioning patients to new formulations and undercutting generic competition before product life-cycle management becomes illegal anticompetitive behavior? A recent lawsuit against Actavis subsidiary Forest Laboratories-manufacturer of memantine (Namenda) addresses this question. ${ }^{14}$ An N-methyl-D-aspartate (NMDA) receptor-blocking agent, memantine was approved to slow cognitive decline in patients with moderate-to-severe Alzheimer's disease. When memantine's market exclusivity was set to expire in 2015, Forest sought to transition patients from twicedaily memantine to once-daily memantine extended-release (Namenda XR). To do so, Forest dramatically limited access to memantine as it introduced memantine XR. The combined action of reformulating and withdrawing the older product is known as a hard, or forced, switch. These tactics caught the attention of the New York State Attorney General's Office, which initiated litigation against the drugmaker for alleged anticompetitive behavior. The outcome of the case has important clinical implications for vulnerable patients, has cost implications for commercial insurance companies and government payors such as Medicare and Medicaid, and tests the boundaries of product life-cycle management behavior.

\section{The Memantine Case}

The controversial actions preceding the memantine litigation arose as the drug's patent term was set to expire in July 2015 (Figure 1), by which time Forest had enjoyed almost 12 years of market exclusivity-and more than $\$ 10.2$ billion in total revenue ${ }^{15}$ - since memantine's original 2003 approval. ${ }^{16}$ With 


\begin{tabular}{ll}
\hline FIGURE 1) & Timeline of Key Events in the \\
& Memantine and Memantine XR \\
& Product Life Cycles
\end{tabular}

2003

- October: The FDA approved memantine.

2004

- January: Forest Laboratories launched memantine.

2010

- June: The FDA approved memantine XR.

2013

July: Forest launched memantine XR.

2014

- February: Forest announced its anticipated August

discontinuation of memantine.

- February: The New York Attorney General's Office initiated an investigation against Forest for anticompetitive conduct.

- September: Attorney General Eric Schneiderman filed a complaint with the court against Forest for antitrust violations.

November: Instead of discontinuing memantine, Forest executed a limited distribution agreement with Foundation Care.

\section{5}

- July: The expiration of the memantine patent term.

- July: Generic manufacturers launched their products.

- August: The end of the preliminary injunction that prohibited

Forest from discontinuing memantine.

\section{9}

September: The expiration of the memantine XR patent term.

FDA =U.S. Food and Drug Administration; $X R=$ extended release.

memantine intended to be taken twice a day, Forest developed a once-a-day formulation-memantine XR-that the FDA approved in June 2010. ${ }^{17}$ However, Forest did not start formally distributing memantine XR until 3 years later in July 2013, foregoing profits on the drug during that time in anticipation of its product hop..$^{18}$ The patent-protected exclusivity period for memantine XR does not expire until 2029.19,20

On February 2014, Forest announced that it would discontinue memantine distribution by August 2014. Because there would be no generic memantine alternatives between August 2014 and July 2015, Alzheimer's disease patients taking memantine at the time would be forced to switch to memantine $\mathrm{XR}$, and all new initiators would be required to receive memantine XR. Forest's strategy was to get patients accustomed to taking memantine XR and physicians accustomed to writing memantine XR prescriptions in advance of the loss of exclusivity for twice-daily memantine.
On the one hand, this tactic might be viewed positively as encouraging use of a medication improved by a slightly more convenient dosing schedule. On the other hand, Forest's switch strategy would undermine the market for the forthcoming generic memantine. Unless there is a compelling clinical or financial reason, patients and physicians tend not to change medications-even more so for Alzheimer's disease patients with cognitive deficits. Once patients are initiated with, or transitioned to, memantine XR, they would be unlikely to switch, or switch back, to generic memantine upon generic market entry in 2015. This tactic was aided by the fact that generic manufacturers generally do not market their products because state automatic substitution laws treat all FDAdesignated A-rated generics as interchangeable in order to facilitate competition based on price. Notably, these same state laws also do not treat the memantine formulation as interchangeable with the memantine XR reformulation

With this dilemma hanging over the marketplace, New York Attorney General Eric Schneiderman began investigating the question of whether the discontinuation of memantine, together with the introduction of memantine XR, anticompetitively interfered with generic competition. In September 2014, the attorney general formally filed a complaint against Forest for violating the Sherman Act, the main federal antitrust law that prohibits monopolies from impeding competition and from coercing consumers into purchasing a particular product. ${ }^{21}$ In response, on November 2014, Forest announced that instead of discontinuing memantine, it would execute a distribution contract with Foundation Care, a mail-order specialty pharmacy. As the exclusive distributor of memantine, Foundation Care would honor only memantine prescriptions accompanied by a special medical necessity form. Of course, many providers would be unwilling to take such a step when memantine XR-a reasonable, convenient alternative-would be available without additional paperwork. Moreover, many patients would prefer a drug they could receive from their local pharmacy. Forest projected that fewer than 3\% of patients would continue on memantine after the Foundation Care plan was initiated.

As seen in Figure 2, memantine XR's launch was associated with a decrease in memantine prescriptions perhaps because a small number of patients proactively switched to memantine XR. Figure 2 also shows that by the end of 2014, after Forest announced the withdrawal of memantine, almost 10,000 memantine prescriptions transitioned to 10,000 memantine XR prescriptions. The early price of memantine XR matched the price of memantine to encourage transitioning of patients. These trends suggest that this product life-cycle management strategy would have successfully transitioned a large number of 


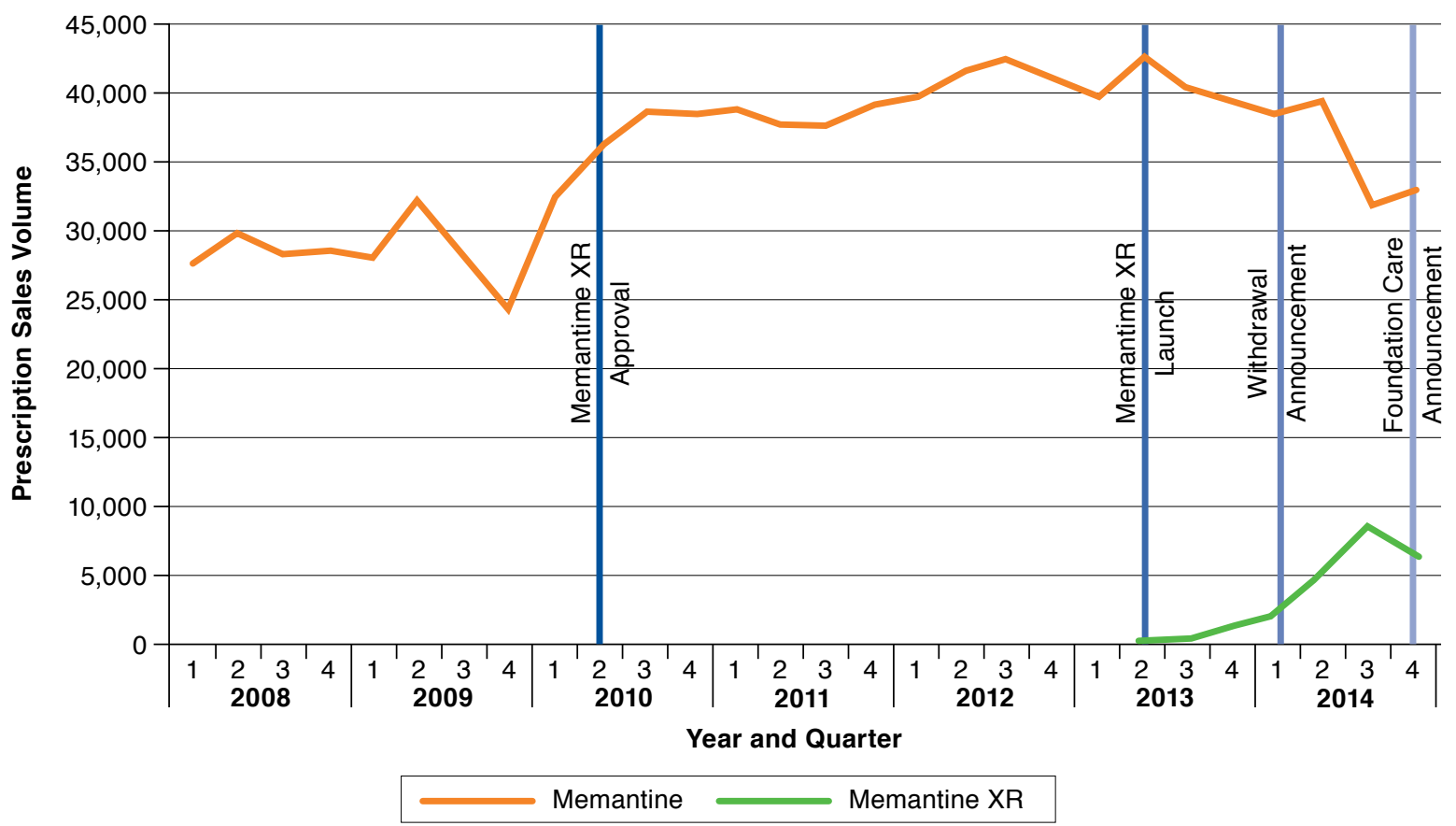

Source: Medicaid drugs program data \& resources. Medicaid.gov. ${ }^{31}$

$X R=$ extended release.

patients to memantine XR before generic versions of memantine became available.

Forest's Foundation Care strategy did not placate the New York State Attorney General's Office, which maintained its lawsuit because the effect of the limited distribution would be almost as severe as discontinuing memantine. Reviewing this case without previous controlling precedent specific to pharmaceutical product hopping, the federal U.S. District Court in the Southern District of New York concluded in December 2014 that Forest's hard switch could be anticompetitive because it undermined the generic market and forced consumers into receiving memantine XR. While patent owners maintain the right to decide whether to "practice their inventions," the court pointed out that they may not use their patent rights to actively interfere with competition. Consequently, the court issued an injunction forcing Forest to maintain production volume of memantine and to continue distribution through regular channels until August 2015, 1 month after generics became commercially available.

In May 2015, the Second Circuit Court of Appeals upheld the order. Case law emerging from disputes in other industries indicated that when a monopolist withdraws its product while compelling consumers to purchase another similar product it sells, then the manufacturer may be acting in violation of the Sherman Act. Accordingly, writing for a unanimous court, Judge Walker ruled that "the combination of withdrawing a successful drug from the market and introducing a reformulated version of that drug, which has the dual effect of forcing patients to switch to the new version and impeding generic competition, [violated] the Sherman Act."22

A "soft switch" alternative would likely have met the court's parameters. Such a strategy would have involved distributing memantine XR at the same time as memantine, giving providers and patients the opportunity to choose the appropriate treatment regimen as opposed to the manufacturer dictating that choice. Still, this choice would be deeply influenced by a shift in the manufacturer's marketing strategy to the newer product. Furthermore, antitrust scrutiny of product hopping as demonstrated in this case could discourage drugmakers from life-cycle management that emphasizes incremental product reformulations. Instead, the court's holding encourages manufacturers to invest—preferentially—in developing innovative drugs.

Importantly, the court also dismissed Forest's claim that branded companies may legally compete against generic drugmakers by trying to undermine generic substitution, which Forest dismissively called "free riding." The court chose to support the 
generic substitution system built by the 1984 Hatch-Waxman Act and state drug product selection laws. In fact, federal food and drug law supports generic substitution by facilitating efficient generic market entry to prevent extensions of pharmaceutical monopolies much beyond the length of the patent term.

Antitrust laws were designed to protect the public's interest against "conduct [that] threatens to reduce competition... [and conduct that threatens] economic harm to consumers." ${ }^{23} \mathrm{Had}$ the hard switch occurred, consumers could have paid, by 1 estimate, an additional $\$ 300$ million, insurers an additional $\$ 1.4$ billion, and Medicare an additional $\$ 6$ billion over 10 years. ${ }^{23}$ Thus, this injunction protected patients from unnecessary changes in medical care and payers from wasteful costs.

\section{Policy Recommendations}

Patents, FDA laws and regulations, and state drug product selection laws work in concert to provide pharmaceutical manufacturers with market exclusivity periods to recoup their investments and to encourage drug innovation. These laws and regulations also create a pathway for low-cost generic competition to flourish after a brand's market exclusivity ends, reducing drug prices for the benefit of patients and payers. Forest's hard switch strategy upended this dynamic by creating a de facto extension of its memantine monopoly. Although drugmakers may take steps to compete in the market by managing their leading drug products, the memantine case helped uphold the principle that drugmakers cannot anticompetitively limit the reasonable availability of generic drugs.

The court compelled Forest to maintain the 2013 memantine price and volume of distribution until 30 days after generic market entry. By ordering Forest to distribute memantine, the court's preliminary injunction countered the flexibility that brand-name drug manufacturers have to cease production of their products. For example, many manufacturers of antibiotics that have underperformed in sales have withdrawn their products without incident. ${ }^{24}$ After a product's market exclusivity ends, many branded manufacturers halt production of their product because of price competition from generic manufacturers. The difference in the Forest case was the timing; the memantine XR alternative and Foundation Care program added up to a potential antitrust violation.

Not all hard switches necessarily violate antitrust laws. One factor working against Forest was that it had monopoly power over the NMDA antagonist market. However, in markets without demonstrated monopoly power, hard switches may not be anticompetitive. Warner Chilcott, the manufacturer of doxycycline hyclate, moved from capsules to tablets, then altered the dosage strengths and scoring patterns. In that case, a lower court ruled that these switches did not violate antitrust laws because the drugmaker did not have monopoly power; doxycycline hyclate, doxycylcine monohydrate, and in-class alternative minocycline were available. Moreover, there was no anticompetitive effect; third-party payers shifted some of the market to alternative oral tetracyclines when Warner Chilcott reformulated doxycycline hyclate or raised the prices. This analysis explicitly defined the relevant market to include other treatment alternatives in the same class.

Appropriate policy interventions to address product hopping must consider ways to limit manufacturers' ability to implement inappropriate hard switches before any harm to patients occurs, while permitting truly novel drug formulation changes that benefit patients. One approach that could meet both goals would be for manufacturers to notify the Federal Trade Commission (FTC) of any plans to limit distribution of older drug formulations while introducing new versions. Notification would allow the FTC to evaluate the potential market effects of the manufacturer's proposal to determine whether it rises to an anticompetitive level. Ultimately, the FTC can use these cases to define clear rules regarding drugmakers' responsibilities. Giving the FTC the necessary legislative authority and budget for such reviews would be difficult in the current political climate. Still, a law that requires the pharmaceutical industry to provide notice to the FTC has precedent. In 2003, Congress required brand-name manufacturers to notify the FTC about settlement agreements with generic drug manufacturers to prevent anticompetitive "reverse payment" settlements, in which brand-name manufacturers pay generic companies to delay generic market entry. ${ }^{25}$ Just as the FTC reviews these settlements for potential antitrust liability, the FTC may scrutinize product-hopping strategies to determine whether they violate antitrust laws.

Another way to prevent brand-name manufacturers from improperly extending market exclusivity through minor product changes is by re-examining the patentability of the changes. The United States Patent and Trademark Office (USPTO) grants patents according to federal court precedent and to the Patent Act, which includes the requirement that a new product be novel so that patents are not issued for products already known to exist. ${ }^{26}$ In the case of omeprazole, the USPTO granted AstraZeneca a patent on the derivative product-esomeprazole-based on the purification of the s-omeprazole enantiomer. Arguably, esomeprazole could have failed the novelty requirement because it was already included in the racemic omeprazole patent. Patenting a component of the original invention inevitably and inappropriately extends the original patent. In addition, patent law requires a discovery to be sufficiently "nonobvious" over previous discoveries, and it is arguably obvious to chemists, pharmacologists, and even 
medical doctors that to purify an isomer of a racemic drug is to enhance its efficacy, particularly when it is known that one isomer (s-omeprazole) is more effective than the other (r-omeprazole). ${ }^{27}$ If the USPTO and federal courts were to reconsider how they apply the novelty and nonobviousness standards to isomers or other new formulations of pharmaceutical products, it could help reduce opportunities for life-cycle management based on weakly innovative follow-on products. Such a move would be consistent with a number of Supreme Court cases in recent years that have changed overly permissive application of other patent rules to combination products, ${ }^{28}$ genes, ${ }^{29}$ and business methods. ${ }^{30}$

A final way to disincentivize product hopping would be to expand state generic substitution laws to allow pharmacists to automatically substitute across formulations, for example, between salts, isomers, or immediate-release and XR formulations. Unless the new product was truly innovative, this recommendation would greatly minimize the incentive to product hop because it would permit generic competition from the older formulation. Patients would be offered the choice at the pharmacy between a low-cost, twice-daily generic memantine or the once-daily memantine XR. Currently, such a change cannot be made without the need to return to the prescriber for a new prescription, and as a result, the choice is rarely offered to patients at their pharmacies. This proposition, however, would require legislation amending pharmacy laws throughout the 50 states and would face major industry lobbying efforts.

\section{Conclusions}

Hard switches present a policy challenge in the pharmaceutical marketplace. Innovative formulations of widely used prescription drugs may be helpful to patients, but they also add little clinical benefit and prolong revenue-generating market exclusivity. As in the memantine case, antitrust litigation may be a viable solution to hard switches. However, some courts may be reluctant to force manufacturers to continue to produce a product line, and most such investigations are conducted only after the hard switch has been done. Thus, other policy solutions are necessary to maintain a viable generic drug marketplacesuccessfully preventing Forest's hard switch allowed for a burgeoning generic memantine market that may feature 8 or more manufacturers, including Upsher Smith, Mylan, Dr. Reddy's, and Teva. Such changes could help the health care system avoid unnecessary prescription drug costs and protect vulnerable patients from being transitioned to new drug formulations that lack meaningful medical benefit just to increase revenue.

\section{Authors}

VINCENT C. CAPATI, PharmD, MS, is a JD Candidate, University of New Hampshire School of Law, Concord, New Hampshire, and at the time this research was conducted was a summer Research Fellow, Program on Regulation, Therapeutics, and Law (PORTAL), Division of Pharmacoepidemiology and Pharmacoeconomics, Department of Medicine, Brigham and Women's Hospital and Harvard Medical School, Boston, Massachusetts. AARON S. KESSELHEIM, MD, JD, MPH, is Associate Professor of Medicine, Program on Regulation, Therapeutics, and Law (PORTAL), Division of Pharmacoepidemiology and Pharmacoeconomics, Department of Medicine, Brigham and Women's Hospital and Harvard Medical School, Boston, Massachusetts.

AUTHOR CORRESPONDENCE: Aaron S. Kesselheim, MD, JD, MPH, Division of Pharmacoepidemiology and Pharmacoeconomics, Department of Medicine, Brigham and Women's Hospital, Harvard Medical School, 1620 Tremont St., Ste. 3030, Boston, MA 02120. Tel.: 617.278.0930; Fax: 617.232.8602; E-mail: akesselheim@partners.org.

\section{DISCLOSURES}

No outside funding supported this research. To support his work at PORTAL in the summer of 2015, Capati was the recipient of the University of New Hampshire School of Law Rudman Center Public Service Fellowship. Kesselheim's research was supported by Greenwall Faculty Scholars program, the Laura and John Arnold Foundation, and the Harvard Program in Therapeutic Science. In 2013, Kesselheim served as an expert on behalf of a class of individual plaintiffs against Warner Chilcott regarding potential antitrust violations.

Kesselheim was responsible for concept and design of this commentary Capati took the lead in data collection and analysis, along with Kesselheim. Capati wrote the manuscript, which was revised by primarily by Kesselheim, along with Capati.

\section{REFERENCES}

1. Cheng J. An antitrust analysis of product hopping in the pharmaceutical industry. Columbia Law Rev. 2008;108(6):1471-515.

2. Carrier MA. A real world analysis of pharmaceutical settlements: the missing dimension of product hopping. Florida Law Rev. 2010;62:1009-36.

3. Abbott Laboratories v. Teva Pharmaceuticals, 432 F.Supp.2d 408 (D.Del. 2006). 4. Mylan v. Warner Chilcott, No. 12-3824, 2015 WL1736957 (E.D. Pa. April $16,2015)$.

5. Walgreen v. AstraZeneca Pharmaceuticals, 534 F.Supp.2d 146 (D.D.C. 2008).

6. Cotton H, Kronstrom A, Mattson A, Moller E, inventors; AstraZeneca, assignee. Form of S-omeprazole. United States patent U.S. 6,369,085. April 9, 2002.

7. AstraZeneca. About Nexium: the healing purple pill. Available at: https:// www.purplepill.com/heartburn-relief.html. Accessed December 23, 2015.

8. Harris G. Prilosec's maker switches users to Nexium, thwarting generics. The Wall Street Journal. June 6, 2002. Available at: http://www.wsj.com/ articles/SB1023326369679910840. Accessed December 23, 2015.

9. Royall MS, Johnson AE, McKenney JC. Antitrust scrutiny of pharmaceutical "product hopping." Antitrust. 2013;28:71-76. Available at: http://www. gibsondunn.com/publications/Documents/RoyallAntitrustScrutinyABA.pdf. Accessed January 7, 2016. 
10. Devlin AJ, Jacobs MS. Anticompetitive innovation and the quality of invention. Berkeley Technol Law J. 2012;27:1-53.

11. Dogan SL, Lemley MA. Antitrust law and regulatory gaming. Texas Law Rev. 2009;87(4):685-729

12. Kesselheim AS. Intellectual property policy in the pharmaceutical sciences: the effect of inappropriate patents and market exclusivity extensions on the health care system. AAPS J. 2007;3;9(3):E306-11.

13. Adams AS, Soumerai SB, Ross-Degnan D. The case for a Medicare drug coverage benefit: a critical review of the empirical evidence. Annu Rev Public Health. 2001;22(1):49-61.

14. Schneiderman v. Actavis, 787 F.3d 638 (2nd Cir. 2015).

15. Actavis Investor Center. SEC filings. April 2014. Available at: http:// investor.frx.com/investor_center/sec_filings. Accessed December 23, 2015.

16. U.S. Food and Drug Administration. Drugs@FDA. FDA approval of Namenda. Letter to Forest Laboratories. October 16, 2003. Available at: http://www.accessdata.fda.gov/drugsatfda_docs/appletter/2003/21487ltr.pdf. Accessed December 23, 2015.

17. U.S. Food and Drug Administration. Drugs@FDA. Approval package for Namenda XR. June 21, 2010. Available at: http://www.accessdata.fda.gov/ drugsatfda_docs/nda/2010/0225250rigls000Approv.pdf. Accessed January 9, 2016.

18. New York v. Actavis, No. 14-CV-7473, 2014 WL 7015198 (S.D.N.Y. Dec. 11, 2014).

19. Rastogi SK, Rao N, Periclou A, Abramowitz W, Dedhiya MG, Mahashabde S, inventors; Forest Laboratories, assignee. Modified release formulations of memantine oral dosage form. United States patent U.S. 8,039,009. October 18, 2011.

20. U.S. Food and Drug Administration. Orange Book: Approved Drug Products with Therapeutic Equivalence Evaluations. Available at: http:// www.accessdata.fda.gov/scripts/cder/ob/docs/patexclnew.cfm?Appl_No= 022525\&Product_No=004\&tablel=OB_Rx. Accessed December 23, 2015.
21. Federal Trade Commission. The antitrust laws. Available at: https:// www.ftc.gov/tips-advice/competition-guidance/guide-antitrust-laws/antitrust-laws. Accessed December 23, 2015.

22. Schneiderman, 787 F.3d 638, 659.

23. Schneiderman, 787 F.3d 638, 661.

24. Outterson K, Powers JH, Seoane-Vazquez E, Rodriguez-Monguio R, Kesselheim AS. Approval and withdrawal of new antibiotics and other antiinfectives in the U.S., 1980-2009. J Law Med Ethics. 2013;41(3):688-96.

25. Federal Trade Commission. Medicare Prescription Drug and Improvement Act requires drug companies to file certain agreements with the Federal Trade Commission and the U.S. Department of Justice. January 7, 2004. Available at: https://www.ftc.gov/sites/default/files/attachments/pharmaceutical-agreement-filings/040106pharmrules.pdf. Accessed December 23, 2015

26. AUL Leahy-Smith America Invents Act. Conditions for patentability; nonobvious subject matter, 35 USC. $\$ 103$ (2011). Available at: https://www.law.cornell.edu/uscode/text/35/103. Accessed January 19, 2016.

27. Metzke M. Targeting enantiomer product hopping with a new "obviousness" standard. UCLA J Law Technol. 2010;14(1):1-31.

28. KSR International v. Teleflex Inc., 550 U.S. 398 (2007). Available at: http://www. supremecourt.gov/opinions/06pdf/04-1350.pdf. Accessed January 22, 2016.

29. Association for Molecular Pathology v. Myriad Genetics, 133 S.Ct. 2107 (2013). Available at: http://www.supremecourt.gov/opinions/12pdf/12-398_lb7d.pdf. Accessed January 22, 2016.

30. Bilski v. Kappos, 561 U.S. 593 (2010). Available at: http://www.supremecourt.gov/opinions/09pdf/08-964.pdf. Accessed January 22, 2016.

31. Medicaid drugs program data \& resources. Medicaid.gov. Available at: http://medicaid.gov/Medicaid-CHIP-Program-Information/By-Topics/ Benefits/Prescription-Drugs/Medicaid-Drug-Programs-Data-and-Resources. html. Accessed December 23, 2015. 